\title{
INDEXING SEASONAL ABUNDANCE OF HUMPBACK WHALES AROUND ABROLHOS ARCHIPELAGO, BAHIA, BRAZIL
}

\author{
Maria E. Morete ${ }^{1,2}$, Richard M. Pace, $\mathrm{III}^{3}$, Cristiane C. A. Martins ${ }^{1}$, Ana C. Freitas ${ }^{1}$, Márcia H. Engel ${ }^{1}$
}

\begin{abstract}
The waters surrounding Abrolhos Archipelago, Brazil, serve as one of several winter grounds for southern-hemisphere humpback whales (Megaptera novaeangliae). Development of tourism in this region has caused concern over disturbance effects to breeding and nursing whales. To document the chronology of humpback abundance around Abrolhos, three years of visualscan data obtained during July through November 1998-2000 were analyzed. During 1-hour scans, observers visually tracked all groups within $9.3 \mathrm{~km}$ and nearly $360^{\circ}$ around a land-based theodolite station to determine group size, composition and behavior. Including only groups of known size, hourly counts $(n=462)$ of adult and calf humpback whales ranged from $0-31$ and $0-9$, respectively. Group size could not be determined for 255 of 2146 groups observed. Humpback whale abundance was seasonal: there were few in early July when surveys began, peaked in early September, and then gradually declined to zero by late November. Based on Poisson regression, the annual chronology of whale occupancy was relatively invariant. Peak counts averaged about 15 adult whales per hour. Although no evidence was found that the timing of peak counts varied, peak abundance varied among years, and more whales were seen during morning than afternoon. The mean number of adults per group did not vary over time (year, day of year, or time of day), but the likelihood of group size being indeterminate varied predictably. Thus, indices of abundance could be adjusted by assuming that the size of indeterminate groups equals mean group size. Calf abundance varied with adult abundance, and the proportion of groups with calves increased from July through November. The high frequency of groups containing a calf $(49.8 \%)$ within $9.3 \mathrm{~km}$ of the Abrolhos Archipelago demonstrated the importance of this area for calves, and proper management is recommended.
\end{abstract}

Resumo - As águas ao redor do Arquipélago dos Abrolhos, Brasil, são uma das muitas áreas de inverno para as baleias jubarte (Megaptera novaeangliae) no hemisfério sul. O desenvolvimento do turismo nessa região e seus efeitos nas atividades de reprodução e cria das baleias, causam preocupação. Para documentar a abundância cronológica de baleias jubarte ao redor de Abrolhos, foram analisados três anos de dados obtidos a partir de varredura visual entre julho e novembro de 1998 a 2000 . Durante varreduras de uma hora, observadores acompanharam visualmente todos os grupos de baleias presentes em 9,3km e aproximadamente $360^{\circ}$ em torno de um ponto fixo equipado com teodolito, para determinar tamanho, composição e comportamento dos grupos. Incluindo somente grupos com tamanho conhecido, as contagens de adultos e filhotes nas varreduras $(n=462)$ variaram entre 0-31 e 0-9 respectivamente. O tamanho de grupo não pôde ser determinado em 255 dos 2146 grupos observados. A abundância foi sazonal: havia poucas baleias no início de julho quando as observações iniciaram, atingindo o pico no início de setembro e decaindo gradativamente até zero no final de novembro. Baseado na regressão de Poisson, a ocupação cronológica anual de baleias jubarte foi relativamente invariável. Em média 15 adultos por hora foram avistados nas épocas de pico. Apesar de não ter sido encontrada evidência de variação de época destes picos, sua abundância variou entre os anos, e mais baleias foram avistadas no período matutino que no vespertino. O número médio de adultos por grupo não variou com o tempo (ano, dia do ano, período do dia), mas a probabilidade de um grupo ter tamanho indeterminado variou. Assim, os índices de abundância da espécie puderam ser ajustados assumindo que o tamanho dos grupos indeterminados equivale ao valor médio de tamanho dos grupos. A abundância de filhotes variou de acordo com a abundância de adultos, e a proporção de grupos com filhote aumentou de julho a novembro. A alta frequência de grupos contendo filhotes (49.8\%) dentro dos 9,3km ao redor do arquipélago demonstra a importância desta área para filhotes e evidencia a necessidade de se estabelecer um manejo adequado da atividade de turismo na região.

Keywords: Abundance index, Abrolhos, humpback whale breeding ground, land-based station surveys.

\section{Introduction}

Breeding and calving grounds of the humpback whale (Megaptera novaeangliae) are typically found near islands or offshore reef systems in tropical or subtropical waters (e.g., Dawbin, 1966; Whitehead and Moore, 1982; Clapham and Mead, 1999). The calm tropical waters surrounding the Abrolhos Archipelago of Brazil are one of several wintering grounds for humpback whales in the southern hemisphere (Rice, 1998). Abrolhos Bank is the only known breeding and calving ground for humpback whales in the western South Atlantic (Siciliano, 1997). Using photo-identification and mark recapture-methods, Kinas and Bethlem (1998) estimated that 1,379 - 1,887 individual humpback whales wintered in the region during 1995.

Because of the attractiveness of the tropical setting and clear waters of the Abrolhos Archipelago, a tourism industry has developed. Popular tourist activities include scuba diving and snorkelling. At present, whale watching is primarily opportunistic, but further development of a whale watching industry seems likely (Morete et al., 2000). There is concern that tourist activities may reach a level that affects whale behavior, seasonality and distribution.

Whale abundance estimates in breeding grounds may fluctuate throughout winter because of their migration patterns (Dawbin, 1966), their local movements (Herman and Antinoja, 1977), and changes in social behavior (Darling et al., 1983; Mobley and Herman, 1985; Mattila et al., 1994). Also, abundance may vary among seasons because some individuals may overwinter in high latitudes (Straley, 1990; Clapham et al., 1993; Swingle et al., 1993). Thus, indexing abundance is a complicated task. There are no published accounts of pre-tourism abundance, group composition or behavior

\footnotetext{
${ }^{1}$ Projeto Baleia Jubarte/Instituto Baleia Jubarte. Praia do Kitongo, Caravelas, Bahia, 45900-000, Brazil.

${ }^{2}$ Universidade de São Paulo, Instituto de Biociências, Departamento de Ecologia. Rua do Matão, 321, São Paulo, SP, 55088-900, Brazil. E-mail: miamorete@terra.com.br.

${ }^{3}$ Northeast Fisheries Science Center, 166 Water Street, Woods Hole, Massachusetts 02543-1026, U.S.A.
} 
at Abrolhos, and knowledge of the consistency with which abundance varies and is influenced by these mitigating factors should prove beneficial for designing future monitoring programs.

Land-based observations of cetaceans are inexpensive relative to vessel-based surveys, but they suffer from limited geographic coverage. Owing to the small area covered, counts will likely be small (in the range of a few to 30) and therefore may be highly variable. Variation may be attributable to animals movement into and out of the observation area within any prescribed observation period, viewing conditions will vary among viewing times, and general abundance of animals using the observation area may vary. Researchers will benefit most from land-based surveys if they have the veracity to detect change and index general whale abundance.

This work summarizes three years of whale-count data collected from a land-based station on Abrolhos Archipelago. These data were used to test whether time of day affects whale counts, and to describe annual variations in whale abundance. This study will form the core of a longterm study to assess possible shifts in humpback abundance and group structure and its relation to the ever-increasing tourist boat traffic.

\section{Material and methods}

\section{Study Area}

Abrolhos Bank $\left(16^{\circ} 40^{\prime}\right.$ to $19^{\circ} 30^{\prime} \mathrm{S}, 37^{\circ} 25^{\prime}$ to $\left.39^{\circ} 45^{\prime} \mathrm{W}\right)$ is located on an extension of the Brazilian continental shelf, on the southern coast of Bahia State (Fig.1). The Bank is a mosaic of coral reefs, mud and calcareous algae bottoms with warm (winter average temperature $=24^{\circ} \mathrm{C}$ ) and shallow (average depth $=c a .30 \mathrm{~m}$ ) waters (IBAMA/FUNATURA, 1991). The extensive coral reef system and other oceanographic features found in the region are similar to those found in the other humpback whale breeding grounds (e.g. Whitehead, 1981; Whitehead and Moore, 1982; Clapham, 1996).

The land-based station ( $17^{\circ} 57^{\prime} 44^{\prime \prime}$ S, 38 $32^{\prime} 22^{\prime \prime}$ W) was located $36 \mathrm{~m}$ above sea level on the western portion of Santa Barbara Island in the Abrolhos Archipelago. Observers from the station surveyed a radius of $9.3 \mathrm{~km}$ ( 5 nautical miles) surrounding the station, except for two areas hidden by islands. There were two blind spots, one to the east part and one to the west, which covered arcs of $8^{\circ}$ and $14^{\circ}$ respectively. Excluding blind spots, the study area was approximately $250 \mathrm{~km}^{2}$ with a maximum depth of $20 \mathrm{~m}$. The Abrolhos Reef, which is a typical reef formation ( $14 \mathrm{~km}$ long by $6 \mathrm{~km}$ wide), covers approximately one fourth of the area, from northeast to southeast (Fig.1).

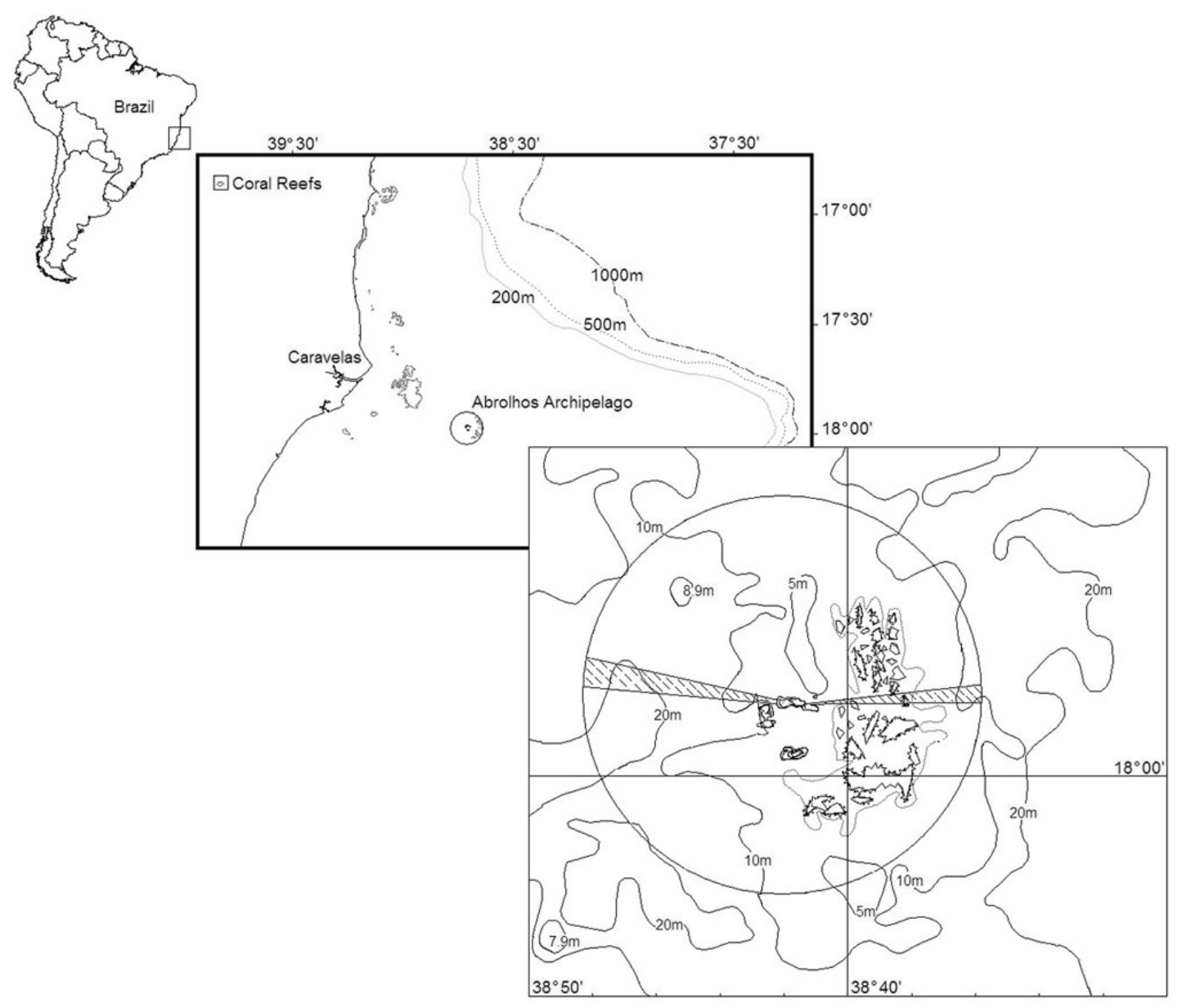

Figure 1. The study area which encompasses a $9.3 \mathrm{~km}$ (5 nautical miles) radius excluding the two blind areas (to east and west) from the land-based station on Santa Barbara Island in the Abrolhos Archipelago, Bahia, Brazil and was visually searched for humpback whales during July-November, 1998-2000. 


\section{Definitions}

A group was defined as either a lone whale or a group of whales with members of the group within $100 \mathrm{~m}$ of each other, generally moving in the same direction in a coordinated manner (Whitehead, 1983; Mobley and Herman, 1985). A calf was defined as an animal in close proximity to another whale, visually estimated to be less than $50 \%$ of the length of the accompanying animal (Chittleborough, 1965), and these animals were presumably born during the current season. All non-calf whales were considered to be adults because of the impossibility of distinguishing subadults from mature individuals.

\section{Observations}

Whales were counted and behaviors noted almost daily during July through November of 1998-2000. Data were not collected during rainy days or when the sea state was 5 (or higher) on the Beaufort scale (winds above 17knots). Data consisted of counts of whales seen during 1-hr scans together with associated behavioral data. Scans were classified according to time of day, as morning or afternoon. Morning scans started from 5:45 to 11:15 and afternoon scans from 12:25 to 16:30.

During each scan, three observers searched for humpback groups within a radius of $9.3 \mathrm{~km}$ of the land-based station. The search was unsystematic, with the naked eye and 7x50 binoculars. Whales were spotted most of the time by a blow, a splash caused by more active behavior or an exposure of a part of their body. Once a group was sighted, one observer (always the same person within the same scan period) tracked the group with a theodolite (30-power monocular magnification) for at least 3 surfacings or until group size, composition and behavioral state were determined. While observing the whales, the observer using the theodolite noted unique characteristics of animals in the group (i.e., scars, natural markings, the shape of dorsal fin) to distinguish the group from any other in close proximity so as to avoid double counting. Sometimes observers continued to watch some whale groups after the one-hour sample period in order to properly determine that group's composition. If movement of several groups concentrating in a small area had caused confusion as to the number of whales, the scan was cancelled, data were discarded and a new one-hour scan was begun. Wind speed at the start and end of scan was measured and the 2 measurements were averaged.

It is possible that some groups present during some scans were not counted. For example groups that remain motionless (logging or resting) in areas of sun glare are difficult to detect. Some groups were sighted only once during the scan and their composition could not be determined. These were termed indeterminate groups, and their impact on the analysis was examined.

\section{Statistical analyses}

Generalized linear modeling procedures (McCullagh and Nelder, 1989) were used to describe and compare the chronology of humpback abundance. In particular, assumed
Poisson distributions and log links were used to model counts of adult whales and calves as predicted by time of day (morning or afternoon), year (1998, 1999, and 2000), day of year (since January 1), day of year ${ }^{2}$, and average wind speed. These predictors and possible 2-way interactions (year by time of day, year by day of the year, year by day of the year ${ }^{2}$, time of day by day of the year, time of day by day of the year ${ }^{2}$ ) were tested by comparing Akiake Information Criterion values (AIC) among fitted models (Burnham and Anderson, 1998). The difference in AIC between competing models and the model with the lowest AIC ( $\Delta$-AIC) was calculated and assumed that there was little evidence to support competing models with $\Delta$-AIC $>4$. A $\Delta$-AIC $=4$ implies that the smaller AIC-valued model has a scaled log-likelihood that is equivalent to a reduction of 2 parameters in the model with the larger AIC. Adult counts were also tested as a predictor of calf count. For these analyses indeterminate groups were assumed to contribute a value of zero to the one-hour abundance index.

Groups varied in composition, especially according to whether or not they contained calves. Hence, variation in the observed proportion of groups with calves for groups of known size across months, years and times of day was examined. Additional analysis of calf presence was used as evidence for the variability in calving rate among years. Adequacy of the final logistic regression model was tested using the goodness of fit test of Hosmer and Lameshow (1989).

Using groups of known size, group size variability was analyzed. Mean group size was regressed against year, day of year, day of year ${ }^{2}$ and time of day. Logistic regression was used in order to test whether the probability of observing an indeterminate group (unknown group size) varied across times of day, years, day of year (since January 1), and day of year ${ }^{2}$. There was concern that a combination of varying group size and a varying likelihood of having groups of undetermined size during the year, might influence our first analysis. Therefore, the first analysis was compared against a similar analysis for which indeterminate groups were assigned appropriate predicted means for the period during which they were observed.

\section{Results}

The data included a total of 462 1-hour scans (Table 1). Humpback whales were observed in the study area from 3 July through 27 November. However, there were sightings before and after our annual observation period (Abrolhos Marine National Park rangers, pers. comm.). During 58 scans, no whales were seen, but 2146 groups were observed during the remaining scans. Two hundred and fifty-five (11.9\%) groups sighted were considered indeterminate, while the remaining 1891 (88.1\%) groups included 4353 humpback whales (942 calves / 3411 adults).

Although counts of adult humpback whales ranged from 0 to 31 and varied considerably (Fig.2) during hourly scans, there was strong evidence that much of this variance was associated with time of day, year, and day of year (Table 2, Fig.3). We found no evidence (Likelihood ratio test $\chi 2=1.09, P=0.296$ ) that counts varied with wind speed. Afternoon counts averaged 
Table 1. Numbers of scans, groups observed (groups with indeterminate number of whales) and whales counted during 1-hr scans of 9.3 km (5 nautical miles) out from Santa Barbara Island in the Abrolhos Archipelago, Bahia, Brazil during July-November, $1998-2000$.

\begin{tabular}{ccccccccc}
\hline \multicolumn{4}{c}{ MORNING } & \multicolumn{5}{c}{ AFTERNOON } \\
\hline Year & Scans & Groups $^{1}($ Ind) & Adults & Calves & Scans & Groups $^{1}$ (Ind) & Adults & Calves \\
\hline \hline 1998 & 106 & $545(78)$ & 848 & 227 & 63 & $300(50)$ & 442 & 109 \\
1999 & 76 & $380(44)$ & 658 & 168 & 62 & $305(40)$ & 490 & 124 \\
2000 & 78 & $335(25)$ & 536 & 171 & 77 & $281(18)$ & 437 & 143 \\
Total & 260 & $1260(147)$ & 2042 & 566 & 202 & $886(108)$ & 1369 & 376 \\
\hline \hline
\end{tabular}

${ }^{1}$ Includes indeterminate groups (Ind)
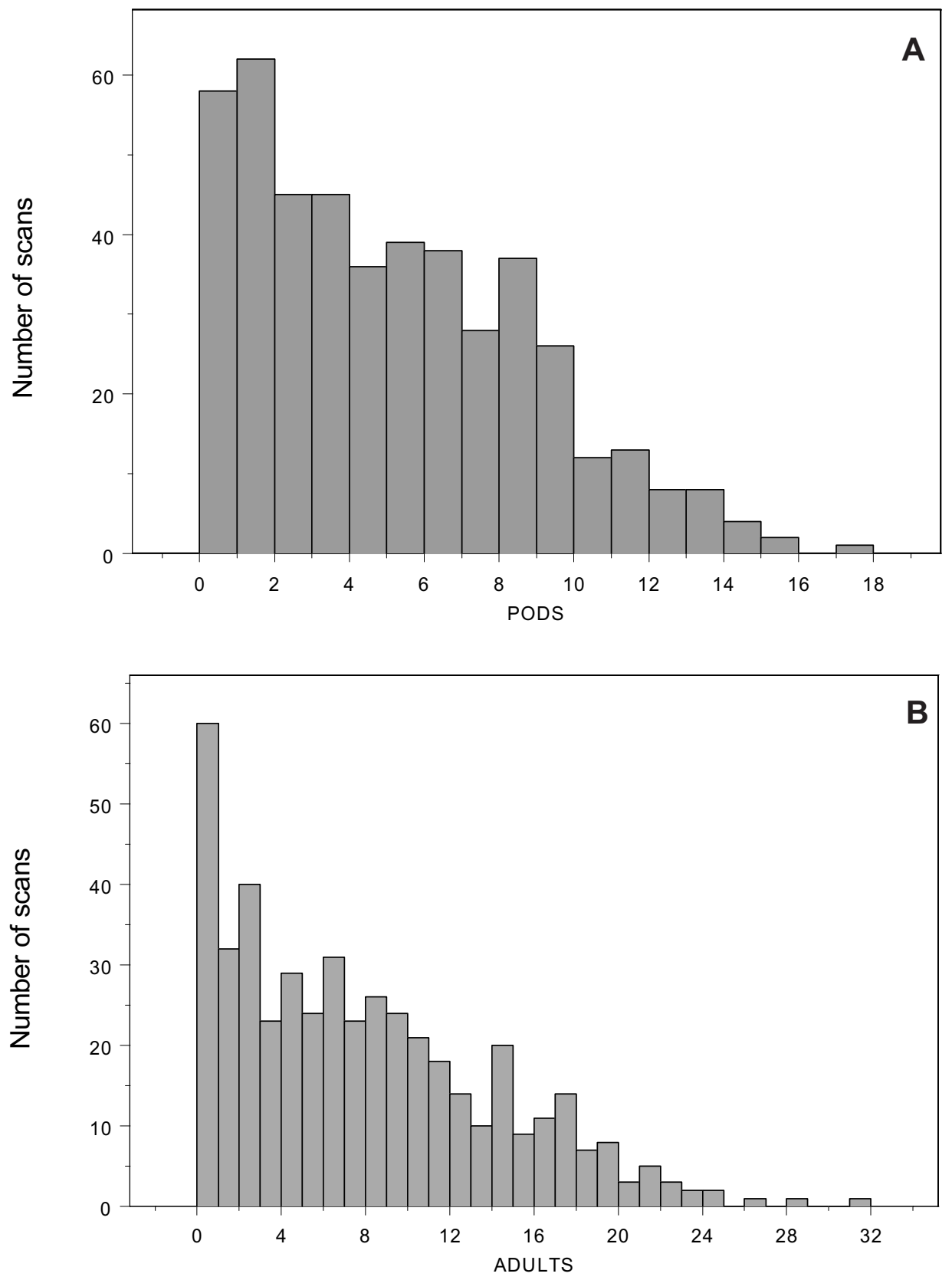

Figure 2. Numbers of groups (A) and adult humpback whales (B) counted during one-hour scans of an $250 \mathrm{~km}^{2}$ circular study area around Santa Barbara Island in the Abrolhos Archipelago, Bahia, Brazil during July-November, 1998-2000. 
4.7\% ( $P=0.0011)$ lower than morning counts. Estimated whale abundance was greatest during 1999 , which was $8.0 \%$ higher than during 1998, whereas, counts during 2000 averaged $6.8 \%$ lower than 1998. Predicted adult humpback whale abundance peaked around September 1, and there was little evidence that chronology of abundance varied among years or between times of day. In general, the number of calves seen during onehour scans varied with number of adults (Table 2) and day of year. About half of all groups seen (49.8\%) contained a calf, but the proportion of groups with calves increased from $<10 \%$ to $>80 \%$ over the season (Fig. 4 ).

Groups ranged in size from 1-10 and averaged $1.80 \pm 0.02$ adults. There was no evidence that mean group size varied among years, within a year or between morning and afternoon scans (all values of $P>0.2$ ). The probability of observing an indeterminate group gradually increased to a

Table 2. Estimated parameters for best fitting generalized linear models used to predict numbers of adult and calf humpback whales counted during 1-hr scans within 9.3km of a land-based station on Santa Barbara Island in the Abrolhos Archipelago, Bahia, Brazil during July-November, 1998-2000.

\begin{tabular}{lccc}
\hline \hline FACTOR & Estimate & SE & t-statistic \\
\hline \hline \multicolumn{2}{l}{ Adult (Null deviance $=2584.15 ;$ Residual } & deviance $=1179.59$ on $456 \mathrm{df}$ ) \\
(Intercept) & -21.6396 & 0.9060 & -23.88 \\
AFTERNOON & -0.0542 & 0.0176 & -3.08 \\
$1999^{*}$ & 0.0688 & 0.0204 & 3.38 \\
2000 & -0.0681 & 0.0127 & -5.36 \\
DAYOFYR $^{+}$ & 0.1986 & 0.0073 & 27.23 \\
DAYOFYR $^{2}$ & -0.00041 & 0.00001 & -28.01 \\
\hline \hline Calf (Null deviance $=967.80 ;$ Residual deviance $=371.58$ on $456 \mathrm{df})$ \\
(Intercept) & -31.1582 & 2.2557 & -13.81 \\
DAYOFYR & 0.2386 & 0.0176 & 13.53 \\
DAYOFYR & \\
ADULTS & -0.00044 & 0.00003 & -13.14 \\
\hline \hline
\end{tabular}

"1998 is taken to be the base year

${ }^{+}$Days since January $1^{\text {st }}$

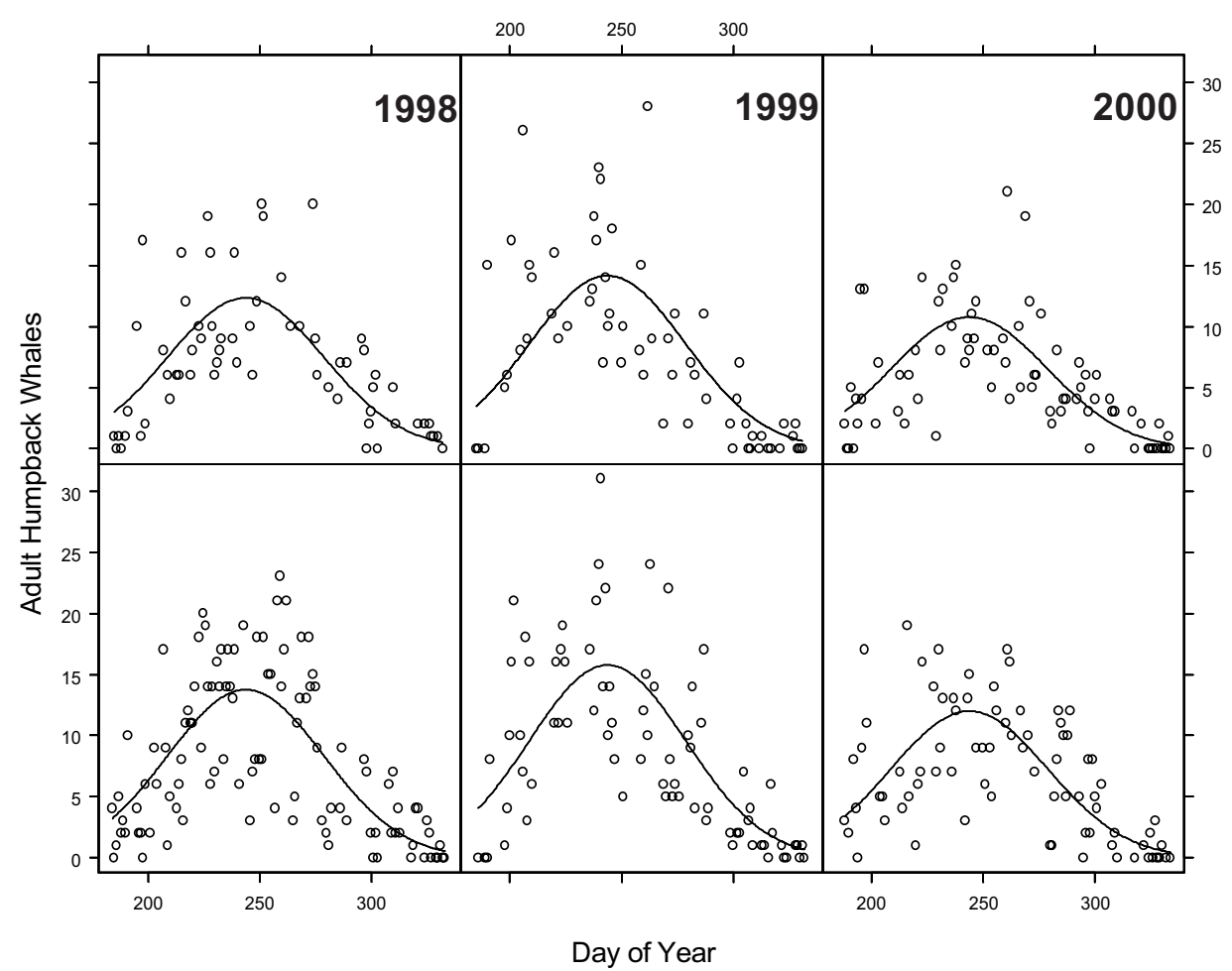

Figure 3. Counts of adult humpback whale plotted together with the predicted relationship between whales counted during one-hour scans, day of the year and year for morning (top) and afternoon scans (bottom). 


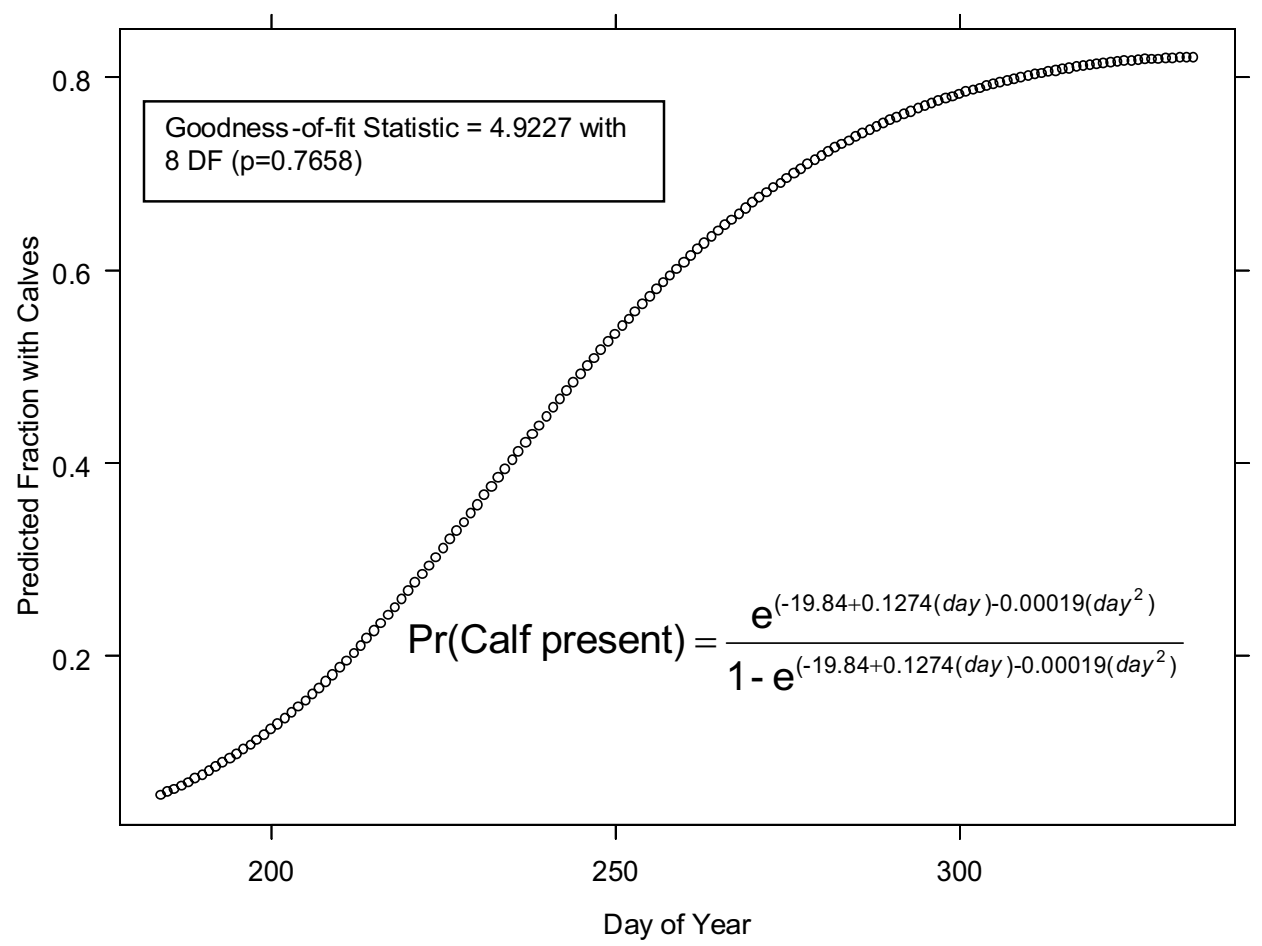

Figure 4. Variation in the proportion of groups containing calves as predicted by logistic regression, from humpback counts during one-hour scans, from July-November, 1998-2000. Goodness-of-fit procedure = 4.9227 with 8 DF ( $P=0.7658)$ followed Hosmer and Lameshow (1989).

peak and then declined each year. There was strong evidence ( $P=0.001)$ that it decreased from 1998 to 2000 . Thus, an index that adjusted whale counts by adding 1.8 adults for each indeterminate group seen during 1998-2000 revealed the same general pattern (consistent chronology, differences among years and differences between times of day) as excluding indeterminate groups, but the size of observed differences among years changed.

\section{Discussion}

The number of humpback whales or groups encountered per unit of time should provide a reasonable index of changes in population size. If the methods used for sighting whales remain the same and the sightability of whales remains reasonably constant, comparisons among years should be valid (Salden, 1988). Platform type, group size, whale behavior, and weatherrelated viewing conditions may influence sightability. Estimates of group size collected from different observation platforms can differ within one study area (Corkeron et al. 1994). Our data on group size were collected from the same observation platform, which is likely to give reasonably unbiased estimates (Bryden et al., 1990; Brown and Corkeron, 1995). Not only was visibility increased because of the platform height, but our observation process did not interfere with whale movements and behavior. To examine the influence of behavior and weather on sightability, it would be necessary to build and compare detectability functions for all behaviors and varying weather patterns. Although the influence of whale behavior on sightability was not tested in our study, the combination of restricting viewing distance to $<9.3 \mathrm{~km}$, elevated platform height, constancy of principal observers and attention to tracking groups reduced the likelihood of any major effects of varying behavior on our index. By restricting observation to periods of low wind (Beaufort < 5), we were able to reduce any effect of wind on sightability below statistically detectable levels. Although the influence of glare and cloud cover were not analyzed, our large sample size (462 scans) reduced the likelihood that differences in viewing conditions among years or time of day influenced our results. There was a significant decrease in the number of indeterminate groups over the three years of this study. This can be interpreted as an increase in skill of the observers. Originally, indeterminate groups were assigned a size of zero. Thus, a more appropriate index would be one that adjusts upward the number of whales seen during a one-hour scan to account for those in indeterminate groups. Making this adjustment did not affect the basic patterns observed, but merely slightly affected the size of the observed differences. The use of a land-based platform with a fixed sample area begs the question as to what population is being indexed by these counts. In particular, differences in counts such as observed among years in this study, may reflect differences in habitat use among years and not population size. Thus, we recognize that our sample may not index the abundance of humpback whales using the whole Abrolhos Bank, even though the area sampled receives high use and is important to humpback whales wintering in the region. Nonetheless because the area is likely to receive increased use by tourists (Morete et al., 2000), establishment of a continuous and consistent index of whale use is essential for assessing local changes in whale behavior. 
If our fixed-area index reflects abundance throughout Abrolhos Bank, then abundance varied among years. The fraction of groups with calves did not vary among years. However, the number of calves seen did vary, because the number of calves varied together with number of adults, and the number of adults varied among years. There is evidence that some individuals overwinter in high latitudes (Straley, 1990; Clapham et al., 1993; Swingle et al., 1993; Brown et al., 1995; Craig and Herman, 1997). Additionally, although not common, switching of wintering areas occurs (Chittleborough, 1965; Darling and Jurasz, 1983).

It is curious that more whales were sighted in the morning than in the afternoon. Because scans were restricted to good viewing conditions, we think it unlikely that differences in morning and afternoon counts were related to differences in viewing conditions. It may be that diel patterns of whale behavior make humpbacks less likely to be seen during the afternoon than in the morning. Helweg and Herman (1994) observed differences in activity levels during morning and afternoon in humpback whales wintering off Hawaii. Their data indicated that resting activity was high at dawn, the most vigorous behaviors peaked at noon, and, although highly visible displays (such as breaching or tail slapping) were generally lacking, late afternoon was still a period of high activity. Clapham (pers. comm.) noted large increases in afternoon dive times for humpback whales wintering in the Caribbean. Hence it is possible that whale behavior influenced sightability at Abrolhos. However it is also possible that fewer whales were present in the study area during the afternoon. Whatever the cause of the observed differences, we recommend that if scan surveys are to be used to index abundance, morning and afternoon survey data should be compared.

The scan data can show considerable random variation. Visible whale groups outside the study area at the start of a session were only counted if they entered the area during the hour. It is precisely this variation which necessitates a statistical model for these data. Our choice of models to describe the chronology of humpback whale abundance was governed by mathematical convenience and fit. A useful formulation for describing whale abundance would be one in which the peak, either its estimated value or the time at which it occurs, is directly estimated. In the present study the simple polynomial models were compared to a nonlinear least square parameterization that directly estimated peak timing, and to another that allowed for considerable asymmetry around the peak. Neither of these models fit (higher deviance of predicted counts) our count data as well as did the Poisson regressions, which have the added advantage of a long history of use on count data (McCullagh and Nelder 1989). Darling et al., (1983) suggested that humpbacks might move through a determined area during winter, leading to variation in the number of whales seen. The models employed detected no rapid influx or exodus of whales. Although the counts were highly variable, the amount of variation seems reasonable for count data that appeared to track a rather smooth chronology of arrivals and departures.

In Abrolhos, mean group size (adults only) was $1.80 \pm 0.02$ and did not vary among years, within a year or between morning and afternoon. This differed from observations in Hawaii and the Caribbean, where larger group size and the formation of competitive groups were in synchrony with humpback peak abundance (Baker and Herman, 1984; Mattila et al., 1989, 1994). At Abrolhos Bank, competitive groups occur in deeper waters than do mother-calf groups (Martins et al., 2001). Smultea (1994) noted that in Hawaii groups with calves occurred predominantly in shallower, more nearshore waters than adult groups, to reduce interactions with conspecifics. Other behavioral studies indicate that cows with calf avoid contact with other whales (Tyack and Whitehead, 1983; Mobley et al., 1988).

The proportion of groups with a calf increases during the breeding season in Hawaii (Herman and Antinoja, 1977; Herman et al., 1980; Baker and Herman, 1984; Salden, 1988; Smultea, 1994). In Abrolhos Bank, Martins et al. (2001), showed that the proportion of lone whales decreases as mother and calf groups increases. This is partly because some of those lone whales are likely pregnant females that give birth along the season. The change in group categories and the proportion of calves observed may also reflect the temporally segregated migration by age and maturational stage (Dawbin, 1966). Some breeding areas of humpbacks in the Caribbean and off Mozambique are considered important nursery areas, because $15 \%$ to $20 \%$ of the groups include calves (e.g. Mattila and Clapham, 1989; Mattila et al., 1994; Findlay et al., 1994). The high frequency of groups containing a calf within 5 nautical miles of the Abrolhos Archipelago seen in this study (49.8\%) together with the observations of Martins et al., (2001), demonstrated the importance of this area for calves, and careful management of this area is recommended.

The relationship between increased localized human activity and the response of whales with calves over a larger region is unclear. Glockner-Ferrari and Ferrari $(1985,1990)$ and Salden (1988) associated a progressive decrease in the percentage of females with calf in nearshore waters off western Maui with an increase in human activities. However, Hawaii's humpback population seems to be increasing despite exposure to human activities (Bauer et al., 1993). The continuation of this long-term study in the Abrolhos Archipelago area may aid in the assessment of possible shifts in humpback abundance and group structure as related to tourism activities.

\section{Acknowledgements}

Funding and support for this research was provided by International Fund for Animal Welfare, Petrobras, Arim Componentes para Fogões, and Parque Nacional Marinho dos Abrolhos- IBAMA. We thank the Brazilian Navy and Pantanal Linhas Aéreas for logistic support. We are indebted to The Projeto Baleia Jubarte interns, without whom the data collection would not have been possible. We also thank P. Clapham, R. Merrick, T. Smith, F. Serchuk, S. Wetmore, J. Reid, and F. Pino for their helpful comments on various drafts of this manuscript. We appreciate the work of R. Baird, an anonymous referee and Eduardo Secchi, who provided reviews greatly improving this manuscript.

\section{References}

Baker, C.S. and Herman, L.M. (1984) Aggressive behavior between humpback whales (Megaptera novaeangliae) wintering in 
Hawaiian waters. Canadian Journal of Zoology 62: 1922-1937. Bauer, G.B., Mobley J.R. and Herman, L.M. (1993) Responses of wintering humpback whales to vessel traffic. Journal Acoustic Society of American 94(3,Pt.2): 1848.

Brown, M.R. and Corkeron, P.J. (1995) Pod characteristics of migrating humpback whale (Megaptera novaeangliae) off the east Australian coast. Behaviour 132: 321-31.

Brown, M.R., Corkeron, P.J., Hale, P.T., Schultz, K.W. and Bryden, M. (1995) Evidence for sex segregated migration in the humpback whale (Megaptera novaeangliae). Proceedings Royal Society of London B: 229-234.

Bryden, M.M., Kirkwood, G.P. and Slade, R.W. (1990) Humpback whales, Area V. An increase in numbers off Australia's east coast. Pages 271-277 in Kerry, K.R.and Hempel, G. (Eds) in Antarctic Ecosystems. Proceedings V Symposium Antarctic Biology. Springer-Verlag, Berlin, Germany.

Burnham, K.P. and Anderson, D.R. (1998) Model selection and Inference: a practical information-theoretic approach. SpringerVerlag, New York, NY, USA.

Clapham, P.J. (1996) The social and reproductive biology of Humpback Whales: an ecological perspective. Mammal Review 26: 27-49.

Clapham, P.J. and Mead, J.G. (1999) Megaptera novaeangliae. Mammalian Species 604: 1-9.

Clapham, P.J., Baraff, L.S., Carlson C.A., Christian, M.A., Mattila, D.A., Mayo, C.A., Murphy, M.A. and Pittman, S. (1993) Seasonal occurrence and annual return of humpback whales in the southern Gulf of Maine. Canadian Journal of Zoology 71: 440-443.

Chittleborough, R.G. (1965) Dynamics of two population of the humpback whale Megaptera nodosa (Bonaterre). Australian Journal of Marine Freshwater Research 16: 33-128.

Corkeron, P.J., Brown, M., Slade, R.W. and Bryden, M.M. (1994) Humpback whales, Megaptera novaeangliae, in Hervey Bay. Queensland. Wildlife Research 21: 293-305.

Craig, A.S. and Herman, L.M. (1997) Sex differences in site fidelity and migration of humpback whales (Megaptera novaeangliae) to the Hawaiian Islands. Canadian Journal of Zoology 75: 1923-1933

Darling, J.D. and Jurasz, C.M. (1983) Migratory destinations of north pacific humpback whales (Megaptera novaeangliae). Pages 359-368 in Payne, R.S. (Ed.) Communication and Behavior of Whales. Western Press, Boulder, CO, USA.

Darling J.D., Gibson, K.M. and Silber, G.K. (1983) Observations on the abundance and behavior of the humpback whales (Megaptera novaeangliae) off West Maui, Hawaii, 1977-79. Pages 201-222 in Payne, R.S. (Ed.) Communication and Behavior of Whales. Western Press, Boulder, CO, USA.

Dawbin, W.H. (1966) The seasonal migratory cycle of Humpback whales. Pages 145-170 in Norris, K.S. (Ed.) Whales, Dolphins, and Porpoises. University of California Press, Berkeley, CA, USA.

Findlay, K.P., Best, P.B., Peddemors, V.M. and Gove, D. (1994) The distribution and abundance of humpback whale on their southern Mozambique breeding grounds. Report International Whaling Commission 44: 311-321.

Glockner-Ferrari, D.A. and Ferrari, M.J. (1985) Individual identification, behavior, reproduction and distribution of humpback whales, Megaptera novaeangliae, in Hawaii. Report Marine Mammal Commission NTIS PB85-200772. 36pp.

Glockner-Ferrari, D.A. and Ferrari, M.J. (1990) Reproduction on the humpback whale (Megaptera novaeangliae) in Hawaiian waters, 19751988: the life history, reproductive rates and behavior of known individuals identified through surface and underwater photography. Report International Whaling Commission Special Issue 12: 161-169.

Helweg, D.A. and Herman, L.M. (1994) Diurnal patterns of behaviour and group membership of humpback whales (Megaptera novaeangliae) wintering in Hawaiian waters. Ethology 98: 298-311.

Herman, L.M. and Antinoja, R.C. (1977) Humpback whales in the Hawaiian breeding waters: population and pod characteristics. Scientific Reports of the Whales Research Institute. 29: 59-85.

Herman L.M., Forestell P.H. and Antinoja, R.C. (1980) The 1976/ 77 migration of humpback whales into Hawaiian waters: the composite description. Report Number. MMC-77/19, Marine Mammal Commission, Washington, D.C., USA.
Hosmer Jr., D.W. and Lameshow, S. (1989) Applied logistic regression. John Wiley and Sons, New York, NY, USA. 307pp.

IBAMA/FUNATURA (1991). Plano de Manejo: Parque Nacional Marinho dos Abrolhos. Brasília. 96pp.

Kinas, P.G. and Bethlem, C.B.P. (1998) Empirical Bayes abundance estimation of a closed population using mark-recapture data with application to humpback whales, Megaptera -novaeangliae, in Abrolhos, Brazil. Report of the International Whaling Commission. 48: 447-450.

McCullagh, P. and Nelder J.A. (1989) Generalized linear models, $2^{\text {nd }}$ Edition. Chapman and Hall, London. 511pp.

Martins, C.C.A., Morete, M.E., Engel, M.C., Freitas, A.C., Secchi, E.R. and Kinas, P.G. (2001) Aspects of habitat use patterns of humpback whales in the Abrolhos Bank, Brazil, breeding ground. Memoirs of the Queensland Museum 47(2): 563-570.

Mattila, D.K and Clapham, P.J. (1989) Humpback whales, Megaptera novaeangliae, and other cetaceans on Virgin Bank and in the northern Leeward Islands, 1985 and 1986. Canadian Journal of Zoology 67: 2201-2211.

Mattila, D.K., Clapham, J.P., Katona, S.K. and Stone, G.S. (1989) Population composition of humpback whales, Megaptera novaeangliae, on Silver bank, 1984. Canadian Journal of Zoology 67: 281-285.

Mattila, D.K., Clapham, P.J., Vasquez, O. and Bowman, R.S. (1994) Occurrence, population composition and habitat use of humpback whales in Samana Bay, Dominican Republic. Canadian Journal of Zoology 72: 1898-1907.

Mobley, J.R. and Herman, L.M. (1985) Transience of social affiliations among humpback whales (Megaptera novaeangliae) on the Hawaiian wintering grounds. Canadian Journal of Zoology 63: 762-772.

Mobley, J.R., Herman, L.M. and Frankel, A. (1988) Responses of wintering humpback whales (Megaptera novaeangliae) to playback recordings of winter and summer vocalizations and of synthetic sound. Behavior Ecology and Sociobiology 23: 211-223.

Morete, M.E., Freitas, A.C., Engel M.H. and Glock, L. (2000) Tourism characterization and preliminary analyses of whale watching on Humpback Whales (Megaptera novaeangliae) around Abrolhos Archipelago, southeastern Bahia, Brazil. SC/52/WW6. Working paper presented to the International Whaling Commission, 2000.

Rice, D.W. (1998) Marine mammals of the world: systematics and distribution. Special Publication Number 4. Society for Marine Mammalogy, Lawrence, KS, USA.

Salden, D.R. (1988) Humpback whale encounter rates offshore of Maui, Hawaii. Journal of Wildlife Management 52: 301-304.

Siciliano, S. (1997) Características da população de baleias jubarte (Megaptera novaeangliae) na Costa Brasileira, com especial referência aos Bancos de Abrolhos. MSc Thesis, Universidade Federal Rural do Rio de Janeiro: Rio de Janeiro - Brazil. 113pp.

Smultea, M.A. (1994) Segregation by humpback whale (Megaptera novaeangliae) cows with a calf in coastal habitat near the island of Hawaii. Canadian Journal of Zoology 72: 805-811.

Straley, J.M. (1990) Fall and winter occurrence of humpback whales (Megaptera novaeangliae) in Southeastern Alaska. Pages 319-323 in Hammond, P.S., Mizroch, S.A. and Donovan, G.P. (Eds) Individual recognition of cetaceans: Use of photo-identification and other techniques to estimate population parameters. Reports of International Whaling Commission, Special issue 12

Swingle, W.M., Barco, S.G. and Pitchford,T.D. (1993) Appearance of juvenile humpback whales feeding in the nearshore waters of Virginia. Marine Mammal Science 9: 309-315.

Tyack, P. and Whitehead, H. (1983) Male competition in large groups of wintering humpback whales. Behaviour 83: 132-154.

Whitehead, H.P. (1981) The behavior and ecology of the humpback whale in the Northwest Atlantic. PhD Thesis, University of Cambridge, UK.

Whitehead, H.P. (1983) Structure and stability of humpback whale groups off Newfoundland. Canadian Journal of Zoology 61: 1391-1397.

Whitehead, H.P. and Moore, M.J. (1982) Distribution and movements of West Indian humpback whale in winter. Canadian Journal of Zoology 60: 2203-2211.

Received 12 December 2002. Accepted 04 February 2003. 